\title{
Indledning
}

\section{Børn og barndomme}

\section{Af Sarah Højgaard Cawood, Malou JuelskJÆr og Jette Kofoed}

temanummer har vi ladet kategorierne køn, børn og barndom mødes for at undersøge, hvordan og hvilke forståelser der kan produceres $i$ et sådant møde. Hensigten med temanummeret er at belyse børn i et flerdimensionalt landskab, hvor kønnede børn lever - og hvor kategorier skabes og genskabes - i komplekse og hybride forhold. Vi har valgt at lade to forholdsvist etablerede forskningsfelter krydse. Dele af diskussionen om køn og børn og de to felters muligheder for at tilføje hinanden inspiration ligger 'inde' i de enkelte artikler, mens andre dele af dis-kussionerne ligger 'imellem' artiklerne. De ligger i mødet mellem artiklerne og i afstanden eller overlapningen mellem artiklerne.

Krydsfeltet mellem køn, børn og barndom udforskes af dette nummers artikler fra meget forskellige vinkler. Hos Erica Burman møder vi et fokus rettet mod undersøgelsen af eksisterende paradigmer eller diskurser for, hvad barndom er for en størrelse og de forandringer sådanne paradig- 
mer gennemgår i en neo-liberalistisk tidsalder. Burman demonstrerer, hvordan pædagogiske, videnskabelige og populært udbredte modeller for børns udvikling står i en gensidighedsrelation til samtidige politiske og økonomiske dagsordener. Og her spiller kønnet en central rolle: Den udvikling barnet, ifølge toneangivende pædagogiske og psykologiske teorier, skal tage fra en afhængig, feminint konnoteret plads til at blive et rationelt og autonomt subjekt skal samtidig garantere politiske visioner om social forbedring. Med senkapitalismen, globaliseringen og neoliberalismen sker der med nye pædagogiske strategier også en række opbrud i de kønnede barndomsforståelser, som Burman eftersporer og problematiserer: Er pigerne nu blevet de nye undervisningsstrategiers idealmodtagere med deres stereotype kvaliteter? Og bliver det neoliberale subjekt feminiseret $\mathrm{i}$ en grad, så kvinder er bedre til at realisere de globaliserede mål? Eller hvordan skal man forstå de forskellige tegn, der viser sig på den kønnede barndoms arena?

I Sarah Højgaard Cawood og Malou Juelskjærs artikel fokuseres på et særligt aspekt af de processer, der skaber subjektivitet eller identitet hos børn (og andre individer), nemlig hvordan aktører bliver til gennem kropslig aktivitet og sanselighed. Artiklen er dels en teoretisk udarbejdelse af et sæt analyseredskaber, der kan være brugbare når kropslig subjektivering eftersøges, samtidig er den et stykke empirisk analysearbejde, som nærlæser, hvordan en ung piges betydningsproduktion af - og dermed positionering i - et reklamebillede skaber bestemte måder at blive en teenagepige på. En bliven til hvor billede, blik, krop og seksualitet fletter sig sammen.

I Oddbjørg Skjær Ulviks artikel kommer børnene til syne som familiesituerede subjekter i et studie af plejefamilier. Her har vi med konkrete børn at gøre, men samtidig med lokale fortællinger om barndom, i det børnenes evne til at leve op til adxkvat barnlighed problematiseres af børnenes plejeforældre. I gennem det Ulvik kalder et generationsbegreb, overfører hun ideen om, at vi gør køn til ideen om at vi gør barn/forældre, som en gensidigt polariserende aktivitet, der skaber kategorierne forxldre/børn. Ved at se på hvordan plejefamilier producerer familieskab og børn/voksenrelationer skaber Ulvik samtidig et selvfølgelighedsopbrud, som gør aspekter af det normative familieskab og den normale forældre/barnrelation synlige, herunder ikke mindst hvor magtgennemsyret en idealiseret institution familien også er.

Jette Kofoed beskriver normalitetspraksisser, som de gøres blandt drenge på skolens fodboldbane. Med denne artikel er vi med andre ord kommet til analysen af børn og køn på mikroniveau, en konkret situation, hvor børn bliver til som kønnede subjekter i en lokalt forankret kontekst og i forhandling med hinanden. I gennem drengenes forsøg på at gøre elevhed på passende vis, når de dagligt vælger hold på fodboldbanen, demonstrerer Kofoed, at normalitet og eksklusion ikke kan reduceres til enkeltstående kategorier (f.eks. piger og drenge, sorte og hvide), og at normalitet ikke kun forhandles gennem sociale, men også gennem lokalt bestemte kategorier, som blander sig med hinanden i daglige afgørelser af hvad der er passende.

Dorthe Staunæs' essay diskuterer hjerneforskningens aktuelle opblomstring som legitimering af biologiserede kønsstereotyper af skolebørn og kønsfastholdende pædagogiske problemløsningsforslag. Med disse fastfrysninger af $k ø n$ sættes snævre dagsordener for hvad barndommens piger og drenge har mulighed for at blive for størrelser, hvilke barndomsparadigmer der er virksomme og hvilke formål disse paradigmer legitimerer og muliggør.

Temanummeret har endvidere forsøgt sig 
med en forskningsvoxpop. Her har temaredaktionen bedt tre forskere reflektere over et 'vigtigt fund'. Det har de gjort på henholdsvis et metodisk, et empirisk/analytisk og et teoretisk niveau. Vi får tre hurtige glimt af disse refleksioner. Dorte Kousholt beskriver det metodiske scoop, som gav hende adgang til feltarbejde i familien: Forskning i sovepose. Hvor en del forskning om levet børneliv foretages på institutioner, bl.a. fordi institutionernes halvoffentlige karakter gør adgangen for forskeren relativt uproblematisk, har Kousholt med soveposen $i$ hånden fået adgang til familiens private rum.

Ann-Carita Evaldssons empirisk/analytiske fund viser, at når man går helt ned $\mathrm{i}$ detailprocesserne i studierne, f.eks. af pigers måder at spille bold, bliver en ellers overset flertydighed synlig. Evaldsson viser, hvordan pigerne pendler mellem 'drenge'-strategier og 'pige'-strategier.

Tuula Gordons teoretiske fund er et spørgsmål om forholdet mellem lokalt forankrede metaforer - her "wallflower" (bænkevarmer) og agens. Er det lettere at blive til en wallflower, fordi metaforen findes og er der dermed mindre handlemulighed for de piger, der ikke kommer på dansegulvet? Hvad betyder det så, at der ikke findes en lignende metafor for de stille drenge hvad bliver de til og er der større handlemulighed eller mere usynlighed forbundet med en unavngiven subjektgørelse?
Udover artiklerne rummer temanummeret også gengivelser af værker af kunstneren Kathrine Ærtebjerg. Ærtebjergs værker er ikke udvalgt for at kommentere, endsige visualisere, de enkelte artikler. Men Ærtebjerg kommenterer sine egne billeder. Og det er især i dét forhold - altså forholdet mellem Ærtebjergs billeder og billedteksterne - at vi har fundet finurlige kommentarer til de steder børn og køn befolker, og vi har fundet foruroligende refleksioner over de transformationer som hele tiden gøres. Det var netop den slags underfundige billeder, som vi gerne ville lade ledsage alle ordene om køn og børn.

I mellem disse artikler og billeder ligger flere uåbnede diskussioner. En af dem er spørgsmålet om hvilke tavsheder, der måtte være $\mathrm{i}$ de to etablerede forskningsfelter, som vi har bragt i søgelyset. Undervejs i arbejdet med dette nummer blev særligt et spørgsmål ved med at vende tilbage: Er der mon mere køn i børneforskningen, end der er børn i kønsforskningen? Spørgsmålet er uudfoldet og bevæger sig i mellem de skrevne artikler og billederne. Det kan måske belyses, måske udfordre eller måske drille i læsningen.

Vi opfordrer hermed læserne til at (med)undersøge og (med)undre i læsningen, i pauserne mellem artiklerne og i billederne og deres tekster, og til at (med)udfordre etablerede forståelser af, hvordan 'det nu er med' køn og børn og barndomme. 